\title{
The Effectiveness of Distribution In The Program Implementation Rice For The Poor ( Raskin) In area Bilah Barat Labuhanbatu Regency.
}

\author{
Zafar Siddik Pohan',Heri Kusmanto' ${ }^{2}$, Walid Musthafa ${ }^{3}$ Mhd. Riswan 4 \\ Faculty social science and political science \\ Departement political science \\ Email: zafarpohan4@gmail.com
}

\begin{abstract}
The Raskin program is a program that carried out under the responsibility of the department of the interior and perumbulog in accordance with skb ( a joint decree ) interior minister with the director main state company bulog number 25 tahun 2003 dan Nomor: PKK-12/07/2003. As for Raskin aims as a form of government efforts in fulfilling their need foodstuffs and to reduce the burden on the community who had income low. A fact about there are still manypolicy there is a shortage of / weaknesses in the Raskin program to the public also occurred in region bilahbarat, as the data researchers get in the field that in the area bilahbarat that the number of poor people is still high by 1904 the head of the family. Of regionbilahbarat areas have been because raskin rice in the target distribution of reasons why there are still weaknesses as that has been in explain above, this is what makewriter feel are attracted to try research surrounding the raskin program in region bilahbarat.

This study aims to determine the level of effectiveness in distribution of the rice poor people( raskin) in bilahbarat areas, poor distribution of the rice is an important thing for a beneficiary to the registered in central raskin, the distribution of in do with the regulations that have been in decreed .

The methodology that was used to research this is the method with the approach kualitatif. technic descriptive data collection with the collection of primary data in the form of interviews and observation field, and collecting secondary data in the form of documentation and the study literature available .The determination of informants in this research using a technique purposive the sampling method of, where informants in this research as many as 10 people which was made up from the camatbilahbarat areas, raskin coordination teams and the community bilahbarat areas.

The result of this research showed that the distribution of rice program poor ( raskinthis in general it can be said effective .View the public about the program has also can be described as good .
\end{abstract}

Keyword: Effectiveness ,Disrtibusi ,Raskin , The Program

\section{PRELIMINARY}

Every country in this world surely has done development for their country.Development is a basic thing to do for every country to keep welfare and advance the life of the people.In essence the state implement development to improve welfare as a whole and comprehensive without making differences about the tribes,religion and gender.In Undang-undangdasar1945, the aim of the development is to improve the piece for all of the indonesian people,hence often heard the term development by the people for the people.

The success of development of a country is determined by availability of qualified human resources (SDM), that SDM should have the strength,a strong mentality, health and smart brain.The results from the study explain that this thing is determined by good nutritional status,and good nutritional status is determined by the amount of food intake consumed.If malnutrition continue to occur this problem can become the obstacle factor of the national development.According to Suryana (2004) in Hendra (2008:78) food endurance and nutrition requires stable equitable and sustainable food supply and prices and the ability of the households to obtain sufficient food and manage it properly so every member get enough nutrition from day to day.The birth of the raskin program is not detached from the monetary crisis that occurred in 1997 that caused the rupiah exchange rate against US Dollar sector declined sharply and hard to control.Then it has affected to a number of sectors especially construction and manufacturer.In this kind of situation, The government intervened in a large scale rice market to lower prices.

At first the government introducing the special market operations or OPK.The purpose is rice with reduced price channeled to poor households as the main target.In 2002, the OPK program transformed into the rice program for poor household (Raskin).The change of the name 
for the program become important,with the Raskinname,the program becomesclearer,then the program can be directly directed to the target,the poor household.The second aim of the program is not very different from the first one,and that is to develop the poor household purchasing power and food insecurity household (Sawit,2002).Raskin program hasa good aim but, in the implementation of the program still lacks a positive contribution to society so even though this program become the government's annual program,Raskin itself still not able to answer the needs of the fulfillment of staple food society of Indonesia (in this case :rice). There is still so many lacks/weakness in this program,one of them is thewrong totarget because of the less coordination between province government with city-districts-village that caused obsolescence of data on the number of poor people.Then the appropriate question of whether this program is indeed the right program to answer the basic needs of the poor people see the allocation of government allocation to each poor household that maximum $15 \mathrm{~kg} /$ month.The fact that there are still many weaknesses in RASKIN program policy to the community also occurred in Bilah BaratDistrict, such as the data that researchers get in the field that in this area of Bilah Baratdistrict that the number of poor people is still relatively high as many as 1904 Head of Family.A subdistrict of Bilah Baratincluding the target area of Raskin due to the existence of weaknesses as described above, this is what makes the author feel interested in doing research on the RASKIN Program in Bilah BaratDistrict.A subdistrict of Bilah Baratincluding the target area of Raskin due to the existence of weaknesses as described above, this is what makes the author feel interested in doing research on the RASKIN Program in Bilah BaratDistrict.

\section{A.Formulation of the problem}

Based on the background that has been described above, then the formulation of the problem to be discussed in this study is "How to Distribute In Implementation of Rice Poor Program (RASKIN) in the District of BilahBarat?

\section{B.Effectiveness Approach}

There are several approaches that can be used to measure the level of organizational effectiveness. Furthermore, Hari Lubis and Martani
Huseini mention there are three main approaches to measuring effectiveness, namely:

\section{RESOURCE APPROACH}

The source approach is to measure the effectiveness of the input. This approach prioritizes the success of the organization to obtain the resources both physical and non-physical that fit the needs of the organization. This approach is based on the theory of the openness of an institution's system to its environment because the institution has a uniform relationship with its environment from which the sources are obtained which is the institution's input and the resulting output is also thrown at its environment. Meanwhile, sources in the environment are often scarce and of high value

\section{A.Process approach (process approach)}

The process approach is to see the extent to which the effectiveness of program execution of all internal process activities or organizational mechanisms. The process approach measures effectiveness with the efficiency and healthcare of an internal agency. In an effective institution, the internal process runs smoothly where the activities of the existing parts run in a coordinated way. This approach is not concerned with the environment but rather focuses on the activities undertaken by the agency that describes the level of efficiency and health of institutions or organizations in carrying out the task.

\section{B.The target approach}

In the target approach where the focus is on the output, it measures the success of the organization to achieve the results (output) in accordance with the plan. This approach tries to measure the extent to which an institution is able to realize the objectives to be achieved. Important targets to be considered in measuring effectiveness with this approach are realistic targets for delivering maximum results based on official official goal targets.Sondang P Siagian argued that the effectiveness of an organization can be measured from various things, namely clarity of the principle, strategic clarity, goal achievement, process analysis and formulation of a stable policy, the availability of facilities and infrastructure effective and efficient, supervisory and control system that is educational . 
There are several factors that can be used to measure the effectiveness of the organization in providing services, among others:

1.Time factor

Timeliness and timeliness of services provided by service providers. It's just that the users of the size of whether or not the speed of service is different from one person to another.

2.Factor of thoroughness

The accuracy factor here is the accuracy factor of the service provider to the customer. Customers will tend to provide a value that is not too high to the service providers in case of many errors.

3.Service delivery style factors

This factor looks at the ways and habits of service providers in providing services to customers.

Distribution

Distribution is needed by consumers to obtain the goods produced by the producers, especially when the production is far. Any activities including the distribution function is divided into two outlines into two.

A. The function of main distribution the main function is the tasks that inevitably have to be implemented. In this case the main functions of distribution include:
1.Transportation In general, where production activities are different from where consumers live, these different places have to be overcome with transportation activities. Along with the increasing number of population and the increasingly advanced technology, human needs more and more. This results in larger distributed goods, thus requiring transportation (transportation).

2.Sales (Selling) In the marketing of goods, there are always selling activities undertaken by the manufacturer. Transfer of rights from the hands of producers to consumers can be done with sales. With this activity, the consumer can use the goods.

3.Purchase (Buying) Every sale means there are also purchasing activities. If the sale of goods is done by the manufacturer, then the purchase is done by the person who needs the goods.

4.Storage (Storing) Before goods are distributed to consumers usually stored first. In ensuring continuity, safety, and integrity of goods, the need for storage (warehousing).

5.Standardized Standards In every buying and selling transaction, many sellers and buyers always require the provision of quality, type and size of goods to be traded. Therefore it is necessary to standardize the standard, size, and quality of the goods to be traded. Standardization of goods is meant for the goods to be marketed or distributed in accordance with expectations.

The RASKIN Flow Mechanism can be seen in the picture below:

\begin{tabular}{|c|c|c|}
\hline $\begin{array}{c}\text { GUDANG } \\
\text { DIVRE }\end{array}$ & $\begin{array}{l}\text { SATKER } \\
\text { RASKIN }\end{array}$ \\
\hline $\begin{array}{l}\text { PENERIMA } \\
\text { MANFAAT }\end{array}$ & $\begin{array}{l}\text { PELAKSANA } \\
\text { DISTRIBUSI }\end{array}$ \\
\hline
\end{tabular}

Image of RASKIN Distribution Flow Mechanism

The effectiveness of Raskin distribution can be assessed through the Raskin program success indicators:

1.Exact Target of Raskin Beneficiaries is only given to beneficiary poor households listed in the beneficiary list (DPM).
2.Exact Quantity Amount of Raskin rice which is the right of beneficiaries is $10-15 \mathrm{Kg} / \mathrm{RTM} /$ month for 10 months.

3.Precise Price The price of Raskin rice is Rp 1,000 / Kg net at the distribution point.

4.Timely Timing of the distribution of rice to beneficiary RTM in accordance with the distribution plan. 
5.Appropriate Administration Fully fulfilling administrative requirements correctly and on time. (BULOG, 2006).

6.Precise Quality, The quality of rice is medium rice good condition in accordance with the quality requirements of rice which is regulated in Inpres Rice Policy in effect.

An efficient distribution system is a prerequisite to ensuring that all households can obtain sufficient quantity and quality of food at all times, at an affordable price. Fairtrade in food among different actors with different powers will ensure an efficient and equitable return. (Nainggolan, 2005,4: 7).All processes in the distribution of marketing, from shelter from producer to distribution of goods to consumers, cost each of which is not the same. When the distance between the manufacturer and the consumer is short, the freight cost can be reduced. If there is no change in shape or volume or quality change then the processing cost is not available. The longer the distance and the more intermediaries involved in the distribution, the higher the distribution cost (Daniel, 2002).

\section{RESEARCH METHOD}

In this research, the writer uses descriptive research method with qualitative approach. Qualitative research aims to reveal information and a deep understanding of the problem of process and meaning by describing a problem. This study is Descriptive that is to describe the reality of the events studied (Sugiyono, 2011: 11).

Based on these explanations, the type or type of qualitative descriptive is appropriate and in accordance with this study as a preliminary study that not only describes something but also interpret and analyze data that has been collected by the authors choose this type of research.

Research sites

This research was conducted in Subdistrict of Bilah BaratJalan Besar KM.4 No.5 Promise Labuhan Batu Regency (INDUK), North Sumatera.

\section{B.Informant Research}

In this study qualitative research subjects are reflected in the focus of research is determined by deliberate, the subject of this research into informants who will provide various information that will be required. Informant research is the subject that understands the object of research information as the perpetrator or others who understand the object of research (Bungin, 2007: 76).Key informants are those who know and have the key informants needed in research or informants who know in depth the problems being studied.Key informants are those directly involved in the social interactions to be studied.Additional informants are those who can provide information Although not directly involved in social interaction to be studied.

\section{A.Data Analysis Technique}

In this study data analysis techniques performed at the time of data collection took place, the data obtained will be organized sorted in the patterns, categories and units of the basic description so that found a description of the problems studied. Data obtained from interviewing techniques will be conducted interactive model analysis (interactive of analysis) developed by Miles and Huberman in Sugiyono (2009: 246) consisting of three components of analysis, namely:

1.Data reduction

Data reduction is done by summarizing and focusing the most important things about the research by looking for themes and patterns to provide a clearer picture and make it easier for researchers to do further data collection and search for it if necessary.

\section{Presentation of data}

Forced as a set of organized information that gives the possibility of conclusion and withdrawal of action.

3. Coclusion

It is a conclusion supported by the evidence and findings found by researchers in the field.

\section{DESCRIPTION OF RESEARCH LOCATION}

A.History of West Bar District

The capital city of Bilah Baratdistrict is Janji Village has a distance to the Capital of the Province of approximately $300 \mathrm{KM}$, the distance to the Capital District is approximately $4 \mathrm{KM}$, the distance to the Office of Regent Labuhanbatu 10 $\mathrm{KM}$ and then the farthest village in the District of Bilah Baratto the Capital District of Sibargot Village approximately 30 KM.Bilah Baratsub-district has boundaries:Northside bounded with North Labuhanbatu RegencyEastside Boundary with Bilah Hulu DistrictSouthern side boundaries with Padang Lawas Utara DistrictWestside adjacent to 
Regency of North LabuhanbatuBilahBarat District (Eighty-two) hamlets. has 10 (ten) Villages and Dusun A total of 82

Table of Population by Sex According to Village of Bilah BaratDistrict 2015.

\begin{tabular}{|c|l|c|c|}
\hline NO & \multicolumn{1}{|c|}{ Village } & Boy & Girl \\
\hline 1 & Sibargot & 1.496 & 1.522 \\
2 & Bandar Kumbul & 2.137 & 1.958 \\
3 & Tanjung Medan & 2.260 & 2.165 \\
4 & Janji & 2.899 & 2.775 \\
5 & Afd. I Rantauprapat & 1044 & 978 \\
6 & Aek Buru Selatan & 142 & 107 \\
7 & Afd. II Rantauprapat & 583 & 520 \\
8 & Kampung Baru & 2.576 & 2.514 \\
9 & Tebing Linggahara & 2.318 & 2.319 \\
10 & Tb. Linggahara Baru & 2.124 & 2.164 \\
\hline \multicolumn{2}{|c|}{ Amount } & 17.579 & 17.022 \\
\hline
\end{tabular}

SourceData: Bilah BaratDistrict In figures of 2015

Potential Areas of Agriculture and Plantation

\begin{tabular}{|c|l|c|c|c|}
\hline NO & Age group & Boy & Girl & Amount \\
\hline 1 & $0-4$ & 2.226 & 2.091 & 4.317 \\
2 & $5-9$ & 1.984 & 1.886 & 3.870 \\
3 & $10-14$ & 1.957 & 1.871 & 3.828 \\
4 & $15-19$ & 1.906 & 1.751 & 3.657 \\
5 & $20-24$ & 1.631 & 1.610 & 3.241 \\
6 & $25-29$ & 1.608 & 1.523 & 2.740 \\
7 & $30-34$ & 1.387 & 1.353 & 2.287 \\
8 & $35-39$ & 1.136 & 1.151 & 2.003 \\
9 & $40-44$ & 1.005 & 998 & 1.644 \\
10 & $45-49$ & 834 & 810 & 909 \\
11 & $50-54$ & 709 & 699 & 593 \\
12 & $55-59$ & 459 & 450 & 973 \\
13 & $60-64$ & 270 & 323 & 34.601 \\
\hline
\end{tabular}

Data Source: West Bilah District In figures 2015

Bilah BaratDistrict in improving services and development to improve the welfare of the community, then in Bilah Baratdistrict we can see the existence of various natural potentials such as agriculture and plantation sector, although including urban areas but still supported from the plantation and agriculture that can increase people's income so that society can prosper.To be able to know more clearly about the agricultural sector and plantations in West Bank West can be seen from the table but divided and started from the agricultural sector such as rice fields are as follows. 
Table :

\begin{tabular}{|c|c|c|c|c|c|c|c|}
\hline NO & Desa & Teknis & $1 / 2$ Teknis & Sederhana & Non PU & $\begin{array}{l}\text { Tadah } \\
\text { Hujan }\end{array}$ & Jumlah \\
\hline $\begin{array}{c}1 \\
2 \\
3 \\
4 \\
5 \\
6 \\
7 \\
8 \\
9 \\
10\end{array}$ & $\begin{array}{l}\text { Sibargot } \\
\text { Bandar Kumbul } \\
\text { Tanjung Medan } \\
\text { Janji } \\
\text { Afd. IRantauprapat } \\
\text { Aek Buru Selatan } \\
\text { Afd. IIRantauprapat } \\
\text { Kampung Baru } \\
\text { Tebing Linggahara } \\
\text { Tb. Linggahara Baru }\end{array}$ & $\begin{array}{l}- \\
- \\
- \\
- \\
- \\
- \\
- \\
- \\
- \\
-\end{array}$ & $\begin{array}{l}- \\
- \\
- \\
- \\
- \\
- \\
- \\
- \\
- \\
-\end{array}$ & $\begin{array}{l}- \\
- \\
- \\
- \\
- \\
- \\
- \\
- \\
-\end{array}$ & $\begin{array}{c}- \\
- \\
67 \\
- \\
- \\
- \\
- \\
- \\
23 \\
-\end{array}$ & $\begin{array}{c}224 \\
- \\
- \\
- \\
- \\
- \\
- \\
45 \\
200 \\
168\end{array}$ & $\begin{array}{c}224 \\
- \\
67 \\
- \\
- \\
- \\
- \\
45 \\
223 \\
168\end{array}$ \\
\hline & Jumlah & - & - & - & 90 & 637 & 727 \\
\hline
\end{tabular}

Tables of Wetland by Type of Irrigation And Village of Bilah BaratYear 2015 (Ha).

Data Source: Bilah BaratDistrict In figures 2015.

From the above table it can be seen that the area of rice fields in District Bilah Barat area of $727 \mathrm{Ha}$, the above data is a decrease in the area used for rice fields and from the monitoring of government apparatus that review is due to the many people who switch to oil palm or plantation sector, but the data received from the survey team still does not show the overall data per village but still global sub-district division of the village has not been divided as a whole in accordance with it can be seen data from the list below.

\section{RESEARCH RESULT}

The effectiveness of an organization can be measured from various things, namely clarity of objectives, clarity of strategy, achievement of objectives, process analysis and formulation of a stable policy, the availability of facilities and infrastructure effective and efficient, supervisory and control system that is educational and tailored to the purpose set previous.Under the Strategic Plan it is an effort to make important decisions and actions that shape and unite how to become a government, what the local government does and why local governments do so. Strategic planning is also comprehensive, medium-term and provides direction covering several stages of the process for its achievement.

The Strategic Plan is also the first step to perform performance measurement that is integrated between human resources with other resources in order to be able to answer the demands of the development of strategic environment. Analysis of the internal and external organizational environment and is a very important step in taking into account the strengths, weaknesses, opportunities and obstacles.The strategic plan that has been established in the Bilah Barat subdistrict office in the implementation of the poor rice program (RASKIN) has set the distribution of Raskin from Kecamatan to the distribution point with the stages specified in the West Bar division, it has been submitted by Mr. H. Aidi Syahmir, S.IPselaku Camat in Bilah BaratDistrict which states:

"Raskin stage is who the recipient has been his person, his stages through bulog district labuhanbatu to the sub-district office of the subdistrict office to distribute to the village, the village conveys to the community that has been registered in the center that cannot be inviolable that as a procedure to get to community and apparatus resources are sufficient, because the apparatus of service to the community is adequate, but so there is guidance to the apparatus so that better service to the community ". (Results of interview on 29 February 2016)

From the above statement, it can be seen that the district party in the stage of raskin distribution has done well and effectively according to the rules that have been determined.To find out how the effectiveness of distribution in the implementation of poor rice program (RASKIN) in Bilah BaratDistrict, researchers use the concept proposed by Martanidan Lubis (1987: 55) on the measurement of effectiveness by using the process approach and target approach. In the process approach, effectiveness is seen from the efficiency and health 
condition of an internal institution in running the work program. This approach does not concern the environment, but focuses on the activities carried out on the resources of the institution. While the target approach where the center of attention on output, measure the success of the organization to achieve the results (output) in accordance with the plan. This approach tries to measure the extent to which an institution is able to realize the objectives to be achieved.The effectiveness of the Raskin distribution program is assessed based on certain criteria in achieving Raskin distribution program objectives. The criteria for the effectiveness of the Raskin program are the targeting of beneficiaries, quantity, price, time, administration and quality, barriers to the implementation of Raskin.

\section{A.Exactly Target Beneficiaries}

Raskin is only given to the Poor Household beneficiaries listed in the Beneficiary List (DPM). Households not included in the criteria are not entitled to receive Raskin. In order to channel the target more accurately, the data collection is done periodically, which is renewed every year by involving the head of the environment and directly supervised by the village officials and BPS apparatus so that any form of deviation or misappropriation can be minimized

Based on clarity on the intended target of Raskin beneficiaries such as the information presented by Mr. Heri Andri as the coordinating team of raskin in westbound districts stated:"Raskin is only given to target families who are enrolled in recipients of raskin. Giving or purchasing poor rice (raskin) is only given to families who really can not afford. Based on the results of the researcher in the field that the poor rice (raskin) is distributed based on the results of the database from the District and based on the results of village consultations to determine who is entitled to receive raskin "(Interview on 29 February 2016).

Exactly Amount

The number of Raskin which is the right of beneficiaries is $15 \mathrm{Kg} / \mathrm{RTM} /$ month for 12 months. This amount is already a right for every Raskin beneficiary and has become a government decision. The amount of rice received by poor households has been very helpful for poor families although not sufficient for a month,but can reduce their expenses in meeting food needs.The implementation of Raskin is said to achieve an appropriate indicator of the number if the RTS-PM receives Raskin rice in an amount consistent with the terms, both in each distribution and in each year of implementation.

Relating to the exact amount in the distribution of raskin rice can be explained by Mr. Heri Andri as coordinating team of raskinstating:"The precise amount of rice distributed to the target. The amount of rice stipulated in the Raskin general guidelines is $15 \mathrm{~kg}$ / month for 12 months with the number of families receiving raskin that is 1 person gets the poor rice (raskin) of $15 \mathrm{~kg} / \mathrm{RTS} /$ month which is in the form of sack $15 \mathrm{~kg}$ sack ". (Results of interview on 29 February 2016).

While the statement of Masriani's mother, a resident of Tanjung Beringin Urban Village west bar:

"I see with the amount of rice I get 15 kg every month maybe it's the provisions of the center" (Results of interview on 29 February 2016).

\section{B.Exactly Amount}

The number of Raskin eligible to receive as Raskin beneficiaries is $15 \mathrm{Kg} / \mathrm{RTM} /$ month for 12 months. This amount is already a right for every Raskin beneficiary and has become a government decision. The amount of rice received by poor households has been very helpful for poor families, although not sufficient for a month, but can reduce their expenses in meeting the food needs. Raskin implementation can be said to reach the right indicator if the RTS-PM receives Raskin rice in the amount consistent with the provisions, both in each distribution and in each year of implementation.

Based on the exact amount in the Raskin rice program distributed to the community concerned as Raskin's beneficiaries amounted to $15 \mathrm{Kg}$ each month in accordance with central government provisions. Thus, the people involved in the Raskin beneficiaries had no complaints about the number of raskin distributed to the $15 \mathrm{~kg}$ beneficiaries.

This can be said in the appropriate indicator of the number of poor rice (RASKIN) distributed by the community concerned in the Raskin beneficiaries can be categorized either because it is in accordance with the provisions and government 
regulations ever month in the distribution to the distribution point of the beneficiaries.

\section{C.Precise Pricing}

The Raskin price is $\mathrm{Rp} 1,600$ / $\mathrm{kg}$ net at the distribution point. The price is the price set by the government. Each household is entitled to get the Rp 1,600 price, but if there is a distribution cost in the distribution of rice, the price of rice may differ depending on the agreement of the distribution executor at the kelurahan level with the beneficiary community. But the price is different after reaching the Raskin beneficiaries. That's because there are additional costs such as for loading and unloading costs, night guard expenses and soforth.Based on the clarity on the exact price of poor rice (RASKIN), the price of Tebus Raskin (HTR) is Rp1,600.00 / kg at the Distribution Point in accordance with the government's provisions, with the additional cost to the Raskin distribution no relation to the government apparatus, in addition to the cost of transport to the distribution point, but not all beneficiaries get the additional cost, there are only some hamlets that are not reached by the implementers in the distribution of poor rice (RASKIN).This can be said in the fixed price of poor rice (RASKIN) in accordance with the provisions of the government with the priceraskin (HTR) of Rp1.600,00 / kg at the distribution point. With the additional costs for the distribution stage of rice raskin (MISKIN) then no longer in pick up again, this can reduce the burden of the community in redeeming the rice at the same price with other civil associated with Raskin beneficiaries.

On timeAccording to Raskin Guidelines, the timeliness of distribution to RTS-PM is achieved when Raskin distribution is carried out in accordance with the distribution plan established by Bulog. The timing of the Raskin distribution to the beneficiary RTM is in accordance with the distribution plan. Raskin distribution has been planned by BULOG for every monthly rice distribution. Timeliness of the distribution will greatly assist the poor in meeting the needs of food.

This is in the distribution of poor rice to the beneficiaries of Raskin can be said to be effective in because distribution is done every month, which is done because it is very helpful to the poor in fulfilling their food needs, the timely distribution of time distribution because Raskin always happens at the beginning of the month, so the distribution of raskin rice can be said in time and in the distribution of poor rice (RASKIN) there are special officers in the distribution.

From the above statement it can be said that the satisfaction of the work or officers in pendisipenyusrtibusianraskinnya with timely in the distribution of each month to the beneficiaries very well.

\section{D.Proper Administration}

Proper administration is defined as the fulfillment of administrative requirements correctly, complete and timely. In the reporting administration the Raskin subdistrict, district / city and provincial coordination teams. Although the Bulog administration reporting has been carried out in an orderly and tiered manner, what Bulog does more reflects the implementation of Raskin to the point of distribution.

This indicates that the kecamatan, district / municipality and provincial raskin coordination teams perform administrative data collection in accordance with Raskin's general guidelines (PEDUM-RASKIN), because of the data that researchers get in the field, with this administrative ordering, making Raskin distribution to the community to be right on target in terms of apportioning raskinnya right to the beneficiaries who really need raskin. With this administrative order also can facilitate the distribution of raskin to the beneficiaries because of the District itself there are lists that are eligible to receive such raskin.

\section{E.Proper quality}

The quality of rice is medium rice, in good condition in accordance with the quality requirements of rice regulated in the current Rice Policy Inpres. However, in the implementation of rice beneficiaries raskin (raskin) some people there who get a rather low quality of rice.However, the quality of rice received by the community in 2015 from the beginning of the distribution of rice to 2016 distribution of rice received by the community as well as the rice rather good and still feasible for consumption by the community.Based on the above description, it can be concluded that the quality of poor rice program (RASKIN) is still 
feasible for consumption by the beneficiary community raskin.

\section{F.Obstacles in the implementation of RASKIN}

Stages of implementation of a program is the most crucial stage in achieving success of a public policy or program. Through this stage will be given a picture of what causes the success or failure of a policy and what factors affect the implementation of the program or policy. This can be seen in the implementation of Raskin program in Bilah Barat district,where there are factors influencing the implementation of this program.In the description that has been described above, then in the implementation of Raskin program there are several obstacles. Based on the results of interviews and observations conducted by the field of researchers, the most important factor is the occurrence of obstacles from the beneficiary community itself due to delays in payment from the community itself, because it cannot redeem the raskin, because raskin rice can not be sold to without being not listed in the center.

\section{CONCLUSIONS AND RECOMMENDATIONS}

As for the conclusion of this research, among others:

1.Poor rice program (RASKIN) is an activity that is given to the community for low income. The Bilah BaratSub-District Office has set the right target of the RASKIN program for 2016 as many as 1904 to be listed as a beneficiary of raskin, viewed from the low income level for the poor.

\section{Right on target}

It can be seen that the provisions and requirements in Raskin beneficiaries in poor rice program (RASKIN) can be categorized on target. Based on the General Guidelines for RASKIN Distribution. 2013. Rice Subsidy for Low Income Communities (Pedum RASKIN). Coordinating Ministry for People's Welfare of the Republic of Indonesia that the provision is entitled to lowincome people.

\section{Exactly Amount}

The implementation of Raskin is said to reach an appropriate indicator of the number if the RTS-PM receives Raskin rice in the amount of $15 \mathrm{~kg}$ in accordance with the terms, both in each distribution and in each year of implementation.

4.Precise Pricing

The price of raskin rice is $\mathrm{Rp} \mathrm{1,600} \mathrm{/} \mathrm{kg} \mathrm{net} \mathrm{at} \mathrm{the}$ distribution point. The price is the price set by the government. Each household is entitled to a price of Rp1,600 / kg.

5.On time

Implementation of the distribution is appropriate because Raskin distribution always occurs at the beginning of the month. So the distribution of raskin rice in time and in the distribution of poor rice (RASKIN) there are special officers in the distribution.

6.Proper Administration

The orderliness of this administration, making Raskin distribution to the community becomes the right target in terms of apportioning raskinnya right to the beneficiaries who really need raskin. With this administrative order also can facilitate the distribution of raskin to the beneficiaries because of the District itself there are lists that are eligible to receive such raskin.

7.Precise Quality

The quality of rice received by the community in 2015 from the beginning of rice distribution until 2016 distribution of rice received by the community as well as rice that is rather good and still feasible for consumption by the community.

8.Obstacles in the implementation of Raskin

The implementation of Raskin program has several obstacles, based on the results of interviews and observations conducted by the field of researchers, the most important factor is the occurrence of obstacles from the beneficiary community itself due to delays in payment from the community itself, because it can not redeem the raskin, because

Raskin rice can not be sold without the not listed in the center.

\section{SUGGESTION}

Suggestions that can be given by researchers related to the effectiveness of distribution in the implementation of poor rice program (RASKIN) in Bilah BaratDistrict Labuhan Batu District are:

1.For the government of Bilah BaratDistrict

a.To avoid the mis-targeting of Raskin in Bilah BaratSub-district, it is expected that the government will recalculate prospective recipients of raskin.

b.The District Government together with the village government work together to implement Raskin Program in accordance with the provisions and fight for the rights of the poor so that it can be fully fulfilled.

2.For the poor of Bilah Barat District 
As citizens should assist in the implementation of Raskin program by participating overseeing the distribution of Raskin rice so that it can be done smoothly and the right of the community as beneficiaries can be fulfilled fairly.

3.For researchers

For the next researcher can oversee the running of a raskin program so that in distribution of raskin rice is well done for the future

\section{REFERENCE}

Amang, B. 1993. Ekonomi Perbesaran, Jagung dan Minyak Sawit diIndonesia. PT Dharma Karsa Utama. Jakarta

Bulog. 2010. Pedoman Umum Raskin (Beras Untuk Rumah Tangga Miskin). Jakarta

Bungin, M. Burhan. 2007. Penelitian kualitatif. Jakarta: Kencana Prenada Media Group

Downey, W.D dan Erickson. 1992. Manajemen Agribisnis. Erlangga. Jakarta

James,L. 2000. Organisasi, Perilaku, Struktur dan Proses. Edisi ke-5. Cetakan ke-3. Jakarta: Penerbit Erlangga..

Hadari, nawawi.1990.Penelitian Bidang Sosial. Yogyakarta: Gajah Mada Press

Hendra. 2008. Ketahanan Pangan. Jakarta

Handewi. 2008. Manajemen Ketahan Pangan Era Otonomi Daerah dan PerumBulog. Bogor.

Hessel Nogi Tangkilisan. 2003. Kebijakan Publik Yang Membumi. Yogyakarta: YPAPI

Jones, Charles O. 1994, Pengantar kebijakan publik. Jakarta: Raja Grafindo Persada

Kerlinger, 1973. Yayasan penelitian perilaku.Edisi II. HRW. Inc

Keban, Yeremias. 2004. Enam Dimensi Strategi Administrasi Publik, Konsep, Teori, Dan Isu. Yogyakarta: Gava Media

Moleong, 2006. Metodologi Penelitian kualitatif. Jakarta: PT. Remaja Rosdakarya

Nainggolan, 2005. Teori Ekonomi Mikro Pendekatan Grafi dan Matematis.Malang : Pondok Edukasi.

Purwadi,.2000. Riset Pemasaran: Implementasi dalam Bauran Pemasaran. Jakarta : Grasindo

Rahim, Abdul dan Diah Retno Dwi Hastuti. 2007. Ekonomika Pertani (Pengantar, Teori, dan Kasus). Penebar Swadaya. Depok
Sondang P. Manajemen Sumber Daya Manusia. Jakarta : Bumi Aksara

Singarimbun, Masri \& Effendi Sofian. 2006. Metode Penelitian Survai. Jakarta: LP3ES

Subarsono. 2005. Analisis Kebijakan Publik. Yogyakarta: Pustaka Pelajar

Sugiyono. 2011. Metode Penelitian Administrasi. Bandung: PT. Alfabeta

Syafa'at, N dan P. Simatupang, 2006. Kebijakan Pamantafan Ketahanan Pangan Nasional ke Depan. Majalah Pangan 15 (47): 24-43.

Tjatjuk. 2011. Manajemen Sumber Daya Manusia Abad 21. Jakarta:

Nusantara Consult

Taff, C. A., 1994. Manajemen Transportasi dan Distribusi Fisis. Jakarta, Erlangga.

Wanggai W. 2012. Menuju Ekonomi Hijau diunduh dari www.setkab.go.id.

William N Dunn. (1994), Public Policy Analysis: An Introduction, Prentice-Hall International, Englewood Cliffs, New Jersey

Winarno, 2002,Teori Dan Proses Kebijakan Publik, Yogjakarta: MadiaPressind

Yunita Sari : Analisis Efektivitas Dan Efesiensi Distribusi Raskin 